\title{
Permeation of losartan across human respiratory epithelium: An in vitro study with Calu-3 cells
}

\author{
MICHELLE AMOAKO-TUFFOUR ${ }^{1}$ \\ POLLEN K. YEUNG ${ }^{2}$ \\ REMIGIUS U. AGU ${ }^{*}$ \\ ${ }^{1}$ Biopharmaceutics and Drug \\ Delivery Laboratory, College of \\ Pharmacy, Faculty of Health Professions \\ Dalhousie University, Halifax \\ NS, Canada B3H $3 \mathrm{J5}$ \\ 2 Pharmacokinetics and Metabolism \\ Laboratory, College of Pharmacy \\ Faculty of Health Professions \\ Dalhousie University, Halifax \\ NS, Canada B3H 3J5
}

Accepted September 16, 2009

\begin{abstract}
The potential for nasal delivery of losartan, a drug with poor oral bioavailability, was investigated using Calu-3 cells. Epithelial permeation of the drug with or without dimethyl- $\beta$-cyclodextrin (DM- $\beta-C D)$ and glycocholate was investigated. Possible transport mechanism of the compound and epithelial mucosal tolerance were screened. Reversibility of epithelial membrane perturbation was also investigated by measuring transepithelial electrical resistance (TEER) recovery over a 24-h period following drug formulation exposure. The permeability coefficient of losartan was $1.3 \pm 0.5 \times 10^{-6} \mathrm{~cm} \mathrm{~s}^{-1}$. This flux was not significantly different from that of formulations containing DM- $\beta-C D(0.5$ and $1.0 \%)$ or glycocholate $(0.5 \%)$. However, the formulation with $1.0 \%$ glycocholate significantly increased losartan permeation 7-fold. Losartan flux across the cells was concentration-dependent. Serosal to mucosal permeation was significantly higher than mucosal to serosal permeation. Concentration-dependency, as well as polarity in transport indicated that the flux of the compound across Calu- 3 cells was not limited to passive diffusion. Cells exposed to DM- $\beta-C D(0.5$ and $1.0 \%)$ and glycocholate $(0.5 \%)$ caused no significant change in TEER and mitochondrial dehydrogenase activity $(\mathrm{MDH})$. The results of the study showed that losartan may be a suitable drug candidate for nasal delivery.
\end{abstract}

Keywords: permeation, losartan, nasal absorption, Calu-3 cells

High blood pressure is the leading cause of stroke and a major risk factor for heart attack and angina pectoris (1). Angiotensin receptor antagonists (ARBs) have been used extensively for treating high blood pressure. Losartan is the first drug in its class to be used clinically for the treatment of high blood pressure. The mode of administration has traditionally been via the oral route. Currently, this drug is administered orally with a bioavailability of about $30 \%$ and a half-life of $1.5-2.5$ hours (2). Its metabolite, (2- $n$-butyl-

\footnotetext{
* Correspondence; e-mail: remigius.agu@dal.ca
} 
-4-chloro-1-[(2'-(1H-tetrazol-5-yl)biphenyl-4-yl)methyl] imidazole-5-carboxylic acid (EXP 3174 ) is more potent and may have therapeutic potentials due to its extended half-life of 3-9 hours (3).

To mitigate some of the problems associated with oral delivery of losartan, it is relevant to explore other possible delivery options such as nasal or pulmonary routes. Data generated from this study will provide some clues on some strategies for improving the bioavailability of the compound by inhalational routes. When administered nasally, some drugs have advantages including the by-passing of hepatic first pass metabolism by the liver, rapid onset of the therapeutic effect, reduced gastrointestinal-related side effects, and attainment of high bioavailability due to higher molecular mass cut-off of the nasal epithelium $(4,5)$. In vitro, ex vivo and in silico models are often used to optimize drug absorption across various biological epithelia (6). These approaches not only speed up drug development process but they lead to cost reduction and offer unique mechanistic possibilities in terms of investigating drug absorption mechanisms and enhancement strategies. In order to assess the potential of losartan for nasal administration, an in vitro cell culture model (Calu-3 cells) was used to screen the absorption characteristics of the compound across the respiratory epithelium. The aim of this study was to explore the possibility of nasal delivery of losartan using an in vitro tissue culture model (Calu-3 cells). Although Calu-3 cells are of tracheo-bronchial origin, we decided to use them because of the similarity between the nasal mucosa and Calu-3 cells and the fact that Calu-3 cells have been used to study nasal drug absorption $(7,8)$. Furthermore, other tracheo-bronchial cells such as EpiAirway ${ }^{\circledR}$ cells have been used to investigate nasal drug absorption in vitro $(9,10)$. Although losartan is a tetrazole non-peptide molecule, it exhibits some characteristics of peptides, such as low transepithelial permeability and antagonism of angiotensin-AT1 receptors. Therefore, strategies used to improve peptide absorption may be employed for this molecule due to its low flux characteristic. The classical approach that we adopted was the use of absorption enhancers (glycocholate and DM- $\beta-C D)$. Glycocholate and DM- $\beta-C D$ were selected because of their efficacy and safety at the concentrations investigated (11).

\section{EXPERIMENTAL}

\section{Materials}

Losartan, its active metabolite EXP 3174 and internal standard for HPLC (5,7-dimethyl-2-ethyl-3-\{[2'-(1H-tetrazol-5-yl)[1,1'-biphenyl]-4-yl]methyl\}-3H-imidazo[4,5-b]pyridine monohydrate (L-158809) were provided as a gift by Merck Sharp and Dohme, USA. Ammonium dihydrogen orthophosphate, acetonitrile, methanol, sodium azide, triethylamine and $N$-2-hydroxyethylpiperazine- $N^{\prime}$-2-ethanesulfonic acid (HEPES) were purchased from Fisher Scientific (Canada). Glycocholate and DM- $\beta-C D$ were purchased from Acros Organics (USA). Tissue culture materials including Dulbecco's Modified Eagle's Medium-Ham's F-12 nutrient (DMEM/F-12), fetal bovine serum (FBS), phosphate buffered saline (PBS), penicillin/streptomycin, glutamax, and phosphate-buffered saline-trypsin were purchased from Invitrogen (Canada). 


\section{Methods}

Cell culture conditions for Calu-3 cells. - Calu-3 cells were generously donated by Dr. Elizabeth Cowley, Department of Physiology Dalhousie University (Halifax, Canada). The cells were maintained in culture using a standard protocol. The cells were cultured in a 1:1 DMEM/F-12 nutrient mixture supplemented with $10 \% \mathrm{FBS}, 100 \mathrm{U} \mathrm{mL}^{-1}$ penicillin, and $100 \mathrm{mg} \mathrm{mL}^{-1}$ streptomycin. Initially, they were grown submerged in the culture medium for 3 days. After this period, they were maintained at an air-liquid interface by not including the culture medium in the donor compartment of the inserts. The receiver compartment contained $1000 \mu \mathrm{L}$ of $10 \%$ FBS, which was changed every $48 \mathrm{~h}$ until the cells were used for transport experiments (usually within 7-10 days post culture establishment). All cell batches were grown on Costar ${ }^{\circledR}$ Transwell ${ }^{\circledR}$ clear (Corning Inc., USA), diameter $12 \mathrm{~mm}, 0.4 \mu \mathrm{m}$ pore-size polyester membrane, in the presence of $5 \% \mathrm{CO}_{2}$ and $95 \% \mathrm{O}_{2}$ at $37{ }^{\circ} \mathrm{C}$.

Permeation studies. - Immediately before permeation studies, the cells were washed twice with transport medium (Hanks' balanced salt supplemented with HEPES buffer and glucose, $\mathrm{pH}$ 7.4). They were the equilibrated by pre-incubation with this medium for 30 minutes at $37^{\circ} \mathrm{C}$. Transport studies were initiated by adding $250 \mu \mathrm{L}$ of losartan to the donor compartment and $1000 \mu \mathrm{L}$ of the transport medium to the acceptor chamber. For concentration-dependency studies, four different losartan concentrations were investigated $\left(50,100,400\right.$ and $\left.5000 \mu \mathrm{mol} \mathrm{L}^{-1}\right)$. At pre-determined time points $(0-120 \mathrm{~min})$, $100 \mu \mathrm{L}$ aliquots were sampled from the receiver compartment (except for studies involving polarity in transport where samples were taken from the donor compartment). The removed samples were replaced immediately with an equal volume of transport medium. The cells were checked for epithelial integrity before and after experiments by measuring transepithelial electrical resistance. The cells were washed with transport medium twice before measuring the resistance. Electrical resistance of the cells was measured using $\mathrm{EVOM}^{\circledR}$, which was connected to an end EV-Ohm Chamber (World Precision Instruments, USA). Additionally, the permeation of $1 \mathrm{mg} \mathrm{mL}^{-1}$ sodium fluorescein was measured after transport studies in order to confirm transepithelial electrical resistance (TEER) studies. This was performed for each batch of experiments. For studies involving reversibility of epithelial perturbation by the formulations, TEER was measured before formulation exposure and was monitored for $24 \mathrm{~h}$. To do this, the cells were washed twice after transport studies and were transferred to new culture media. TEER was subsequently measured at $0,0.25,0.5,0.75,1,3$ and $24 \mathrm{~h}$ time points. During this period, the cells were incubated at $37^{\circ} \mathrm{C}$ with DMEM/F-12 supplemented with $10 \%$ FBS in a stable tissue culture environment $\left(95 \% \mathrm{O}_{2} / 5 \% \mathrm{CO}_{2}\right)$.

Apparent permeability coefficient $\left(P_{\text {app }}\right)$ for losartan transport was calculated according to the following equation:

$$
P_{a p p}=V\left(\frac{d c}{d t}\right) \frac{1}{A c_{0}}
$$


where $\left(\frac{d c}{d t}\right)$ is the linear mass flux to receiver solution, $A$ is the epithelial cell surface area, $c_{0}$ is the initial concentration of losartan in formulation, $V$ is the volume of receiver solution and $t$ is time.

The permeability ratio of the compound was calculated according to the equation (12):

$$
\text { Permeability ratio }=\frac{P_{a p p(B L-t o-A P)}}{P_{a p p(A P-t o-B L)}}
$$

where AP is apical and BL is basolateral. A ratio greater than 1 (12) indicates involvement of an efflux transporter.

3-(4,5-Dimethylthiazol-2-yl)-2,5-diphenyl tetrazolinium bromide (MTT) assay. - MTT assay was used to monitor cell viability following exposure to losartan formulations. At the end of permeation studies, the inserts with Calu-3 cells were washed 3 times by immersion into a beaker of transport medium. Rinsed inserts were transferred into clean 6-well plates, which were filled with $600 \mu \mathrm{L}$ of MTT $\left(2 \mathrm{mg} \mathrm{mL}^{-1}\right)$ so that the solution was in contact with the insert membrane. The cells were then incubated for 3 hours at $37^{\circ} \mathrm{C}$. At the end of the incubation period, the inserts were removed from the MTT solution, blotted dry on a paper towel and transferred to 6-well plates containing $3 \mathrm{~mL}$ isopropyl alcohol (Sigma-Aldrich, Canada). An additional $1.0 \mathrm{~mL}$ of the alcohol was placed on the apical surface of the cells. Formazan crystals were extracted for $2 \mathrm{~h}$ on a Delfia ${ }^{\circledR}$ plate shaker (slow-speed module) (Wallac, Germany) with the inserts sealed with parafilm to prevent evaporation. They were also protected from light with aluminum foil wraps. At the end of the extraction period, the extracted solution from the apical and basolateral sides of the cells were collected and mixed. Subsequently, $700 \mu \mathrm{L}$ of the solution from each insert was transferred to disposable plastic micro-cuvettes. Formazan absorbance was measured spectrophotometrically at $570 \mathrm{~nm}$ using a Cary 50 Bio UV-Visible Spectrophotometer (Varian PTY Ltd, Australia). Isopropyl alcohol solution was used as blank solvent. To improve data quality, absorbance adjustment was made by subtracting the absorbance obtained at $650 \mathrm{~nm}$ from the values at $570 \mathrm{~nm}$.

Losartan formulations used for the transport and toxicity studies were prepared by dissolving a specific amount of losartan powder in phosphate buffered saline. For studies with absorption enhancer, the drug was dissolved in PBS containing either 0.5 or 1.0 $\%(m / V)$ glycocholate or DM- $\beta-\mathrm{CD}$.

High performance liquid chromatography (HPLC). - The assay of losartan by HPLC was based on a previously published method (13) that was validated for this study. The HPLC system consisted of a $250 \times 3.0 \mathrm{~mm}$ internal diameter $\mathrm{C}_{18}$ reversed phase analytical column (Gemi ${ }^{\circledR}$, Phenomenex, USA) with a $4.0 \times 4.0$ mm i.d. $C_{18} 5-\mu \mathrm{m}$ reversed phase cartridge guard column (Lincrocart, Merck, Germany), a Shimadzu SPD-20A UV detector (Shimadzu, USA) set at $254 \mathrm{~nm}$ and an HP 3395 Integrator (Agilent Technologies, USA). The mobile phase comprised $0.01 \mathrm{~mol} \mathrm{~L}^{-1}$ ammonium dihydrogen orthophosphate buffer-acetonitrile-methanol (45:30:25) with $0.02 \%$ sodium azide and $0.04 \%$ triethylamine and final $\mathrm{pH}$ adjusted to 3.2. The system was operated isocratically at ambient tempe- 
M. Amoako-Tuffour et al: Permeation of losartan across human respiratory epithelium: An in vitro study with Calu-3 cells, Acta Pharm. 59 (2009) 395-405.

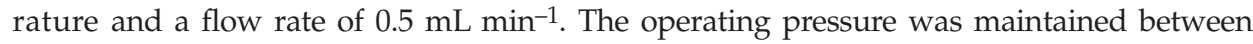
11.7 and $13.7 \mathrm{kPa}$. Losartan, its active metabolite EXP3174 and the internal standard (L-158809) were separated without interference from other compounds (e.g., diltiazem, verapamil, AZT, dipyridamole, nifedipine, cytarabine and propranolol). Precision within assay (or within day) was lower than $10 \%$. The standard curves were linear from 0.1 to $1.0 \mu \mathrm{g} \mathrm{mL}^{-1}$ for losartan and EXP 3174 with an $R$ of 0.9985 and 0.9970 , respectively.

Statistical data analysis. - Unless otherwise stated, each in vitro experiment was performed in triplicate using different inserts and the data were expressed as mean \pm SD. Student's $t$-test was used to compare the effects of formulation excipients on TEER change, sodium fluorescein permeation and tissue viability relative to control (cells incubated with transport medium or PBS).

\section{RESULTS AND DISCUSSION}

Figs. 1a,b show the data on in vitro permeation of losartan, with and without absorption enhancers across Calu- 3 cells. The permeability coefficient ( $P_{\text {app AP-to-BL) }}$ of the
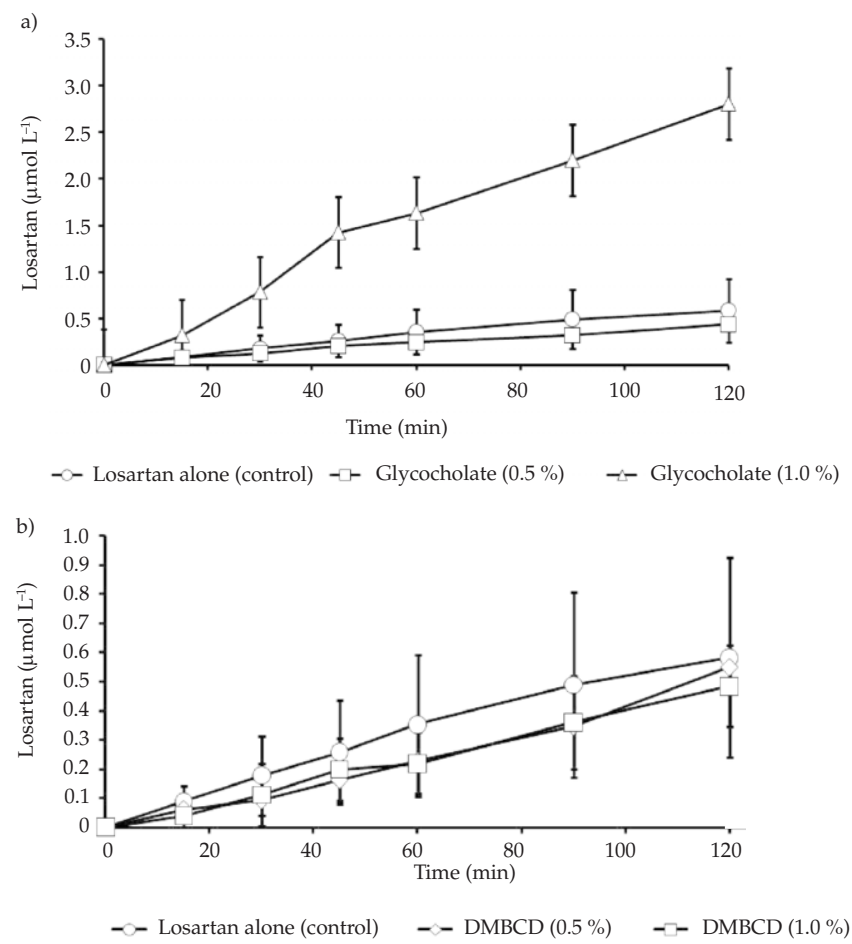

Fig. 1. Permeation across Calu-3 cells of losartan formulated with: a) glycocholate and b) dimethyl- $\beta$-cyclodextrin. Points are mean $\pm \mathrm{SD}, n=3$. 
compound without any formulation additive was $(1.3 \pm 0.5) \times 10^{-6} \mathrm{~cm} \mathrm{~s}^{-1} . P_{\text {app AP-to-BL }}$ in formulations containing absorption enhancers was $(1.3 \pm 0.5) \times 10^{-6}(0.5 \% \mathrm{DM}-\beta-\mathrm{CD})$, $(2.2 \pm 0.2) \times 10^{-6}(1.0 \%$ DM- $\beta-C D),(1.1 \pm 0.1) \times 10^{-6}(0.5 \%$ glycocholate $)$, and $(8.7 \pm 1.1) \times$ $10^{-6} \mathrm{~cm} \mathrm{~s}^{-1}$ (1.0\% glycocholate). The enhancement factor for losartan permeation was 0.9-7.2.

The $P_{\text {app AP-to-BL }}$ for losartan without enhancers was not significantly different from that of the formulations with DM- $\beta-C D(0.5$ and $1.0 \%)$ and glycocholate $(0.5 \%)$. However, there was a significant increase $(p<0.05)$ in the drug absorption with $1.0 \%$ glycocholate. For the formulations investigated, the active metabolite of losartan, EXP3174, was not detected during transport experiments. This implied that losartan was intact during the two-hour permeation period. It is therefore possible that metabolism did not play a limiting role in the compound permeability under our experimental conditions.

Concentration had a significant effect on the flux of the compound. The apical to basolateral transport was concentration-dependent (Fig. 2). The concentration-dependent decrease in permeability coefficient of the compound was observed as concentration increases from 50 to $5000 \mu \mathrm{mol} \mathrm{L}^{-1}$. This could be due to saturation of peptide transporters responsible for active transport of the compound across the epithelial cells. The permeation of losartan across the cells also exhibited polarity in transport.

Results of the bi-directional studies are highlighted in Fig. 3. The losartan permeability coefficient for basolateral-to-apical transport was 8-fold higher than apical-to-basolateral permeation. This possibly implies that the permeation of losartan in Calu-3 cells was limited by an efflux transport system. Losartan flux in Calu-3 cells was 2.6 to 5.2-fold higher than the rates reported for Caco-2 and MDCK cell lines $(14,15)$. Furthermore, the permeability ratio in favour of basolateral-to-apical transport observed in this study (8-fold) was approximately half of the permeability ratio reported for the Caco-2 cell culture system. It is important to emphasize that the permeability coefficient observed for losartan in various epithelial models is relatively low considering the low molecular mass of the compound $\left(422.911 \mathrm{~g} \mathrm{~mol}^{-1}\right)$. Some hypotheses including the possible metabolism by intestinal CYP3A4, first-pass metabolism by the liver and intestinal counter-transport by P-glycoprotein efflux transporters may suffice to explain the low and variable bioavailability of the compound after oral administration. In this study, the low permeation

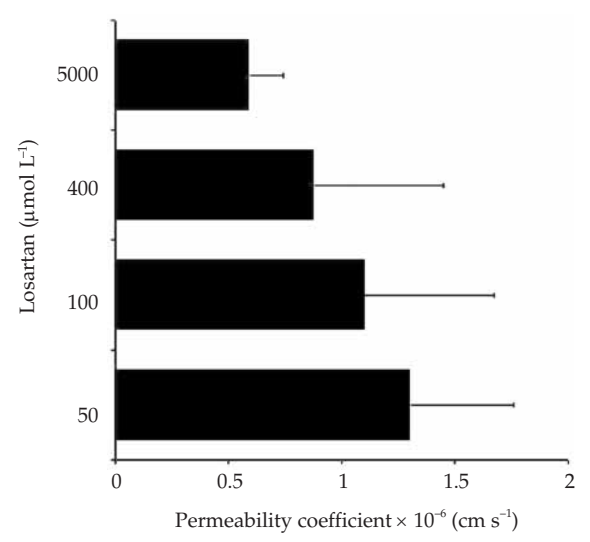

Fig. 2. Effect of losartan concentration on permeation across Calu- 3 cells. Points are mean \pm SD, $n=3$. 
Fig. 3. Effect of polarity on losartan $\left(100 \mu \mathrm{mol} \mathrm{L}{ }^{-1}\right)$ permeation across Calu-3 cells. Points are mean $\pm \mathrm{SD}, n=3$. AP - apical; BL - basolateral.

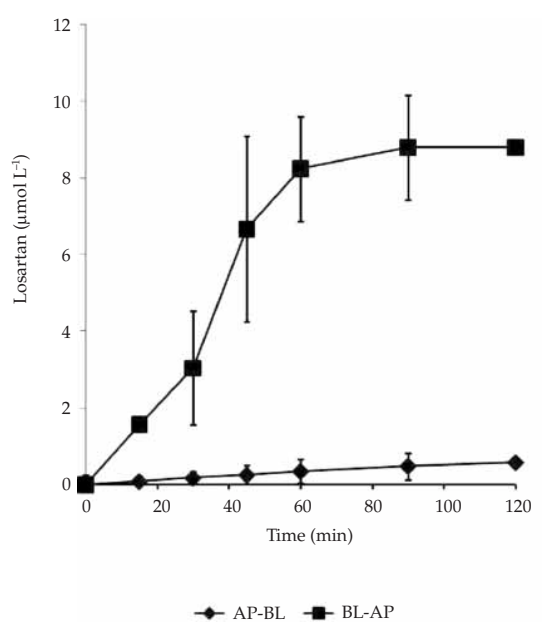

of the compound across the respiratory cells in the absence of an enhancer may not be attributed to its metabolic clearance during transport as EXP371; the major metabolite of the compound was not detected. Losartan is a substrate of P-glycoprotein efflux pump (16), which is expressed in Calu-3 cells (17) and Caco-2 culture systems (18). However, these efflux pumps have not been shown to be expressed in the nasal epithelium. Therefore, the observed efflux in Calu-3 cells may not limit the bioavailability of the compound following nasal administration.

Fig. 4 shows the effect of losartan prepared with absorption enhancers on mucosal tolerance using the decrease in TEER (Fig. 4a) and sodium fluorescein permeation (Fig. $4 \mathrm{~b})$ as toxicity indices. The mean TEER value of the cells before permeation studies was $523 \pm 86(n=12)$. Following exposure to the losartan formulations, the TEER of the cells was between $60-88 \%$ of their initial values. Furthermore, the mean permeation of sodium fluorescein following formulation exposure for $2 \mathrm{~h}$ was $0.7 \pm 0.0 \%$ (glycocholate $0.5 \%$ ), $1.3 \pm 0.1 \%$ (glycocholate $1.0 \%$ ), $1.0 \pm 0.4 \%$ (DM- $\beta-C D 0.5 \%$ ), and $1.0 \pm 0.3 \%$ (DM- $\beta-C D$
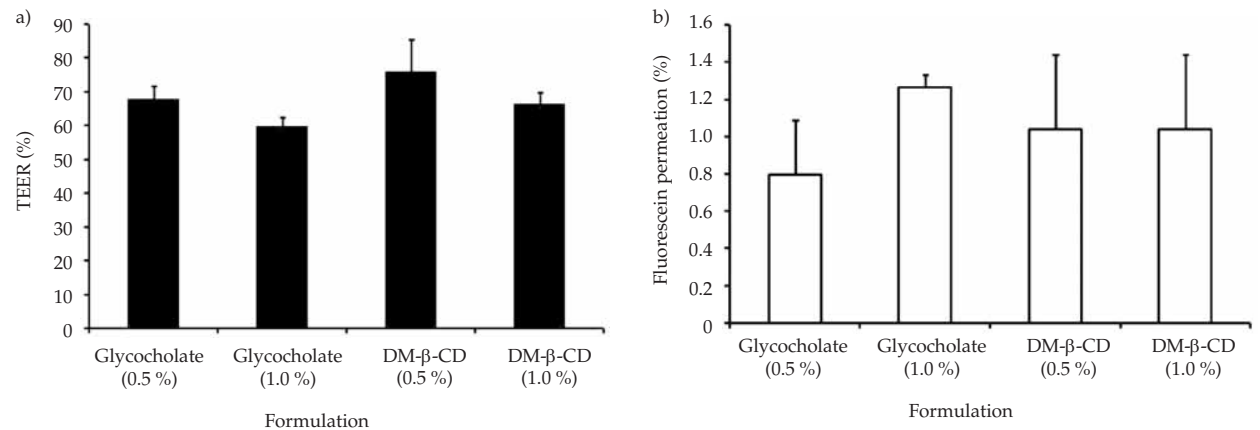

Fig. 4. Effect of losartan formulation on: a) transepithelial electrical resistance and b) paracellular marker permeation in Calu-3 cells. Points are mean $\pm \mathrm{SD}, n=3$. 


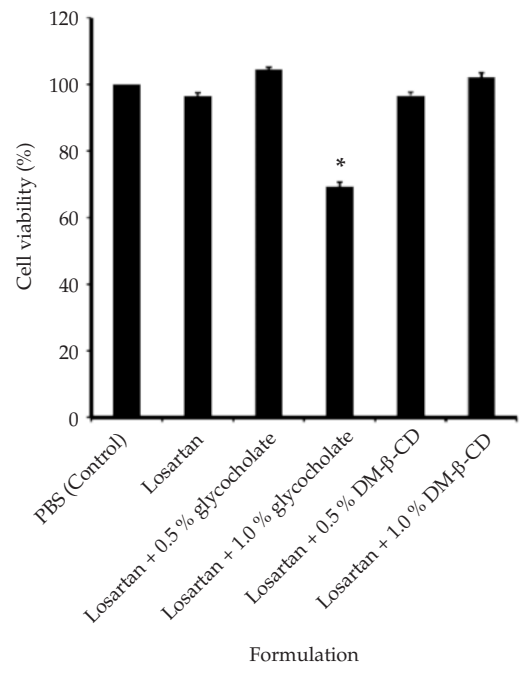

Fig. 5. Effect of losartan formulation on viability of Calu-3 cells after a 2-h incubation period. Points are mean \pm SD, $n=3$. PBS - phosphate buffered saline, DM- $\beta$-CD - dimethyl- $\beta$-cyclodextrin. * - significantly different from control, $p<0.05$.

$1.0 \%)$. Considering the relatively low sodium fluorescein permeation in one hour, and the results of TEER reduction, it appears that the formulations may not have any significant detrimental effect when used in vivo. To support this hypothesis, it was necessary to find out whether the observed TEER reduction and sodium fluorescein permeation were accompanied by significant cytotoxicity. This was investigated by screening the ability of the cells to convert MTT to formazan crystals (mitochondrial dehydrogenase activity, $\mathrm{MDH}$ ) after 2-h incubation with losartan formulation. Viability of the cells after drug exposure is summarized in Fig. 5. Cells incubated with PBS served as a negative control. The MDH activity after treatment with the transport medium was not significantly different from that of the cells exposed to the test compounds, except for cells treated with $1.0 \%$ glycocholate $(p<0.05)$. Considering the effect on epithelial viability that was observed for $1.0 \%$ glycocholate, it was important to find out whether the cells could recover from this effect in a timely manner. Since the MTT assay is a terminal method, it was not suitable to investigate cellular recovery, which is a time dependent effect. As an alternative, we monitored the change in TEER of the cells exposed to the formulations for $24 \mathrm{~h}$ following drug exposure.

Figs. $6 \mathrm{a}, \mathrm{b}$ show the change and recovery of TEER in cells exposed to various formulations of losartan. Cells that were exposed to losartan formulations with glycocholate (Fig. 6a) had a faster recovery rate than cells exposed to DM- $\beta-C D$ formulations (Fig. $6 b)$. For cells exposed to formulations with glycocholate, no significant recovery was observed up to $1 \mathrm{~h}$ after the drug exposure. However, there was significant recovery $(p<$ 0.05 ) after $3 \mathrm{~h}$, especially for cells exposed to formulations with $0.5 \%$ glycocholate. After $24 \mathrm{~h}$ more than $50 \%$ recovery was observed for cells exposed to both 0.5 and $1.0 \%$ glycocholate formulations. As for cells exposed to DM- $\beta-C D$, the recovery pattern was quite different from that of glycocholate. TEER values for the two formulations continued to decline up to $3 \mathrm{~h}$ following drug exposure. A positive change in TEER was observed only after a $24-\mathrm{h}$ recovery period compared to $3 \mathrm{~h}$ observed for glycocholate-containing for- 

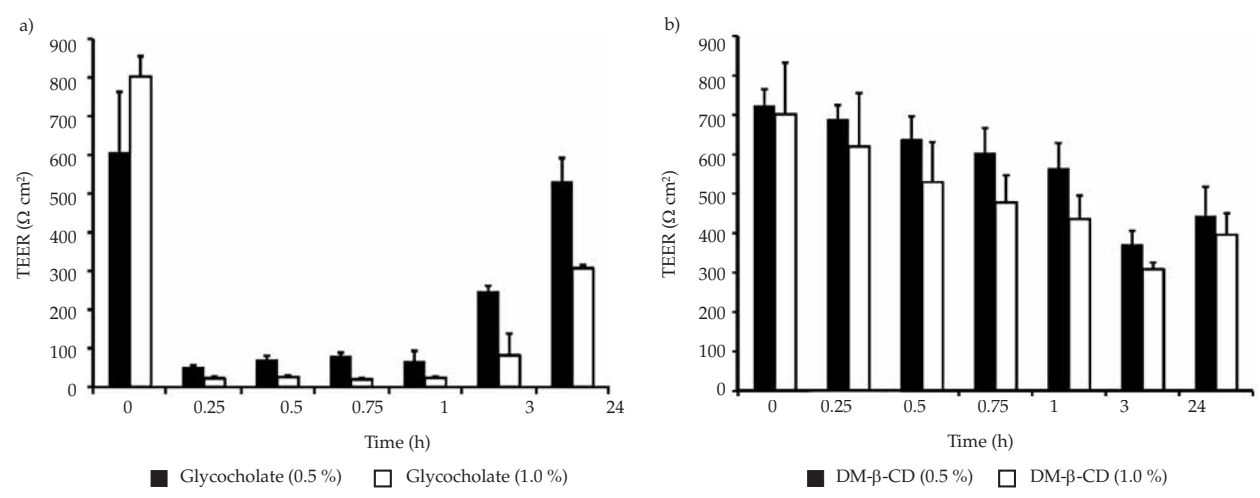

Fig. 6. Reversible effect of losartan formulated with: a) glycocholate and dimethyl- $\beta$-cyclodextrin on Calu-3 cells. Cells were exposed to formulations for $2 \mathrm{~h}$ and reversibility was assessed over a 24-h period. Points are mean \pm SD, $n=3$.

mulations. The most important observation was that within the 24-h recovery period, TEER stopped declining and started to increase. Both the rate of TEER decline and its rate of recovery were concentration-dependent. In general, the cells exposed to the formulations began to recover from the effects of the formulations within $24 \mathrm{~h}$. Although some reports have shown that glycocholate and DM- $\beta-C D$ may cause various degrees of epithelial damage $(19,20)$, these effects may be dependent on the concentration and exposure times of the formulations containing enhancers. Although losartan formulated with $1.0 \%$ glycocholate showed reduced mitochondrial dehydrogenase activity, the observed recovery of TEER within 24 hours following exposure to the formulations implies the possibility of using both DM- $\beta-C D$ and glycocholate in preparing losartan formulations for nasal administration. Reversibility is an important aspect of epithelial perturbation by drugs or formulation excipients because it is rare to have any form of drug absorption enhancement without modification of the tight junction or the epithelial membrane. Therefore, the most relevant issue to consider is the reversibility of epithelial perturbation at the concentration range to be employed for absorption enhancement.

\section{CONCLUSIONS}

Losartan permeation was significantly increased by glycocholate. It also reversibly modified transepithelial resistance. Data generated from this study has provided some insights into the possible absorption enhancement strategies for nasal administration of losartan. Systemic delivery of this compound via the nasal route could result in higher CNS bioavailability and reduction of side effects related to dose escalation common in oral administration.

Acknowledgements. - This research was supported in part by a summer research studentship and a Research Support Grant by the Pharmacy Endowment Foundation, Dalhousie University, Canada. 
M. Amoako-Tuffour et al: Permeation of losartan across human respiratory epithelium: An in vitro study with Calu-3 cells, Acta Pharm. 59 (2009) 395-405.

\section{REFERENCES}

1. F. He and G. MacGregor, Salt, blood pressure and cardiovascular disease, Curr. Opin. Cardiol. 22 (2007) 298-305; DOI: 10.1097/HCO.0b013e32814f1d8c

2. R. Hernandez-Hernandez, B. Sosa-Canache, M. Velasco, M. J. Armas-Hernandez, M. C. Armas-Padilla and R. Cammarata, Angiotensin II receptor antagonists role in arterial hypertension, J. Hum. Hypertens. 16 (2002) S93-99; DOI: 10.1038/sj/jhh/1001352.

3. M. W. Lo, M. R. Goldberg, J. B. McCrea, H. Lu, C. I. Furtek and T. D. Bjornsson, Pharmacokinetics of losartan, an angiotensin II receptor antagonist, and its active metabolite EXP3174 in humans, Clin. Pharmacol. Ther. 58 (1995) 641-649; DOI: 10.1016/0009-9236(95)90020-9.

4. H. R. Costantino, L. Illum, G. Brandt, P. H. Johnson and S. C. Quay, Intranasal delivery: physicochemical and therapeutic aspects, Int. J. Pharm. 337 (2007) 1-24; DOI: 10.1016/j.ijpharm.2007.03.025.

5. M. I. Ugwoke, R. U. Agu, N. Verbeke and R. Kinget, Nasal mucoadhesive drug delivery: background, applications, trends and future perspectives, Adv. Drug Deliv. Rev. 57 (2005) 1640-1665, DOI: 10.1016/j.addr.2005.07.009.

6. R. Agu and M. Ugwoke, In Situ and Ex Vivo Nasal Models for Preclinical Drug Development Studies, in Drug Absorption Studies in Situ, in Vivo and In Silico Models (Eds. C. Ehrhardt and K. Kim), AAPS Pharmaceutical Press, New York 2008, pp. 112-134; DOI: 10.1007/978-0-387-74901-3_5.

7. T. Yang, A. Hussain, J. Paulson, T. J. Abbruscato and F. Ahsan, Cyclodextrins in nasal delivery of low-molecular-weight heparins: in vivo and in vitro studies, Pharm. Res. 21 (2004) 1127-1136; DOI: 10.1023/B:PHAM.0000032998.84488.7a.

8. T. Seki, H. Kanbayashi, S. Chono, Y. Tabata and K. Morimoto, Effects of a sperminated gelatin on the nasal absorption of insulin, Int. J. Pharm. 338 (2007) 213-218; DOI: 10.1016/j.ijpharm. 2007.02.004.

9. R. U. Agu, S. Valiveti, D. C. Earles, M. Klausner, P. J. Hayden, D. P. Wermeling and A. L. Stinchcomb, Intranasal delivery of recombinant human parathyroid hormone [hPTH (1-34)], teriparatide in rats, Endocr. Res. 30 (2004) 455-467; DOI: 10.1081/ERC-200035957.

10. N. V. Chemuturi, P. Hayden, M. Klausner and M. D. Donovan, Comparison of human tracheal/ bronchial epithelial cell culture and bovine nasal respiratory explants for nasal drug transport studies, J. Pharm. Sci. 94 (2005) 1976-1985; DOI: 10.1002/jps.20404.

11. R. U. Agu, H. Vu Dang, M. Jorissen, R. Kinget and N. Verbeke, Metabolism and absorption enhancement of methionine enkephalin in human nasal epithelium, Peptides 25 (2004) 563-569; DOI: 10.1016/j.peptides.2004.02.019.

12. N. Denora, V. Laquintana, A. Lopedota, M. Serra, L. Dazzi, G. Biggio, D. Pal, A. K. Mitra, A. Latrofa, G. Trapani and G. Liso, Novel L-dopa and dopamine prodrugs containing a 2-phenyl-imidazopyridine moiety, Pharm. Res. 24 (2007) 1309-1324; DOI: 10.1007/s11095-007-9255-y.

13. P. K. Yeung, A. Jamieson, G. J. Smith, D. Fice and P. T. Pollak, Determination of plasma concentrations of losartan in patients by HPLC using solid phase extraction and UV detection, Int. J. Pharm. 204 (2000) 17-22; DOI: 10.1016/S0378-5173(00)00453-1.

14. A. Soldner, L. Z. Benet, E. Mutschler and U. Christians, Active transport of the angiotensin-II antagonist losartan and its main metabolite EXP 3174 across MDCK-MDR1 and Caco-2 cell monolayers, Br. J. Pharmacol. 129 (2000) 1235-1243; DOI: 10.1038/sj.bjp.0703150.

15. M. D. Ribadeneira, B. J. Aungst, C. J. Eyermann and S. M. Huang, Effects of structural modifications on the intestinal permeability of angiotensin II receptor antagonists and the correlation of in vitro, in situ, and in vivo absorption, Pharm. Res. 13 (1996) 227-233; DOI: 10.1023/ A:1016086930019.

16. O. von Richter, O. Burk, M. F. Fromm, K. P. Thon, M. Eichelbaum and K. T. Kivistö, Cytochrome P450 3A4 and P-glycoprotein expression in human small intestinal enterocytes and hepatocytes: a comparative analysis in paired tissue specimens, Clin. Pharmacol. Ther. 75 (2004) 172-83; DOI: $10.1016 /$ j.clpt.2003.10.008. 
17. B. I. Florea, I. C. van der Sandt, S. M. Schrier, K. Kooiman, K. Deryckere, A. G. de Boer, H. E. Junginger and G. Borchard, Evidence of P-glycoprotein mediated apical to basolateral transport of flunisolide in human broncho-tracheal epithelial cells (Calu-3), Br. J. Pharmacol. 134 (2001) 1555-1563; DOI: 10.1038/sj.bjp.0704390.

18. T. Korjamo, P. Honkakoski, M. R. Toppinen, S. Niva, M. Reinisalo, J. J. Palmgrén and J. Mönkkönen, Absorption properties and P-glycoprotein activity of modified Caco-2 cell lines, Eur. J. Pharm. Sci. 26 (2005) 266-279; DOI: 10.1016/j.ejps.2005.06.004.

19. Z. Shao, R. Krishnamoorthy and A. K. Mitra, Cyclodextrins as nasal absorption promoters of insulin: mechanistic evaluations, Pharm. Res. 9 (1992) 1157-1163; DOI: 10.1023/A:1015847604654.

20. M. A. Bagger, H. W. Nielsen and E. Bechgaard, Nasal bioavailability of peptide T in rabbits: absorption enhancement by sodium glycocholate and glycofurol, Eur. J. Pharm Sci. 14 (2001) 69-74; DOI: 10.1016/S0928-0987(01)00146-4.

\section{$S A \check{Z} E T A K$}

\section{Permeacija losartana kroz humani respiratorni epitel: In vitro ispitivanja na Calu-3 stanicama}

MICHELLE AMOAKO-TUFFOUR, POLLEN K. YEUNG i REMIGIUS U. AGU

U radu je ispitivana mogućnost nazalne primjene losartana, lijeka sa slabom bioraspoloživošću nakon peroralne uporabe, koristeći Calu-3 stanice. Ispitivana je permeacija lijeka kroz epitel u prisutnosti dimetil- $\beta$-ciklodekstrina (DM- $\beta$-CD) i glikokolata te bez njihove prisutnosti. Predložen je mogući mehanizam transporta kroz epitel i određena je tolerancija epitelne mukoze. Reverzibilnost promjena u epitelu praćena je mjerenjem povrata transepitelnog električnog otpora (TEER) kroz razdoblje od $24 \mathrm{~h}$ nakon izlaganju pripravku lijeka. Koeficijent permeabilnosti losartana bio je $1.3 \pm 0.46 \times 10^{-6} \mathrm{~cm} \mathrm{~s}^{-1}$. Taj se dotok značajno ne razlikuje od pripravaka koji sadrže DM- $\beta$-CD $(0,5$ i 1,0 \%), odnosno glikokolat $(0,5 \%$ ) (faktor povećanja $\approx 1,0)$. Međutim, iz pripravka s $1,0 \%$ glikokolata povećala se permeacija losartana 7 puta. Protok losartana kroz stanice ovisio je o koncentraciji. Permeacija iz seruma u mukozu bila je značajno veća nego u obrnutom smjeru. Ovisnost o koncentraciji te polarnost $\mathrm{u}$ transportu ukazuju na to da protok losartana kroz Calu-3 stanice nije ograničen samo na pasivnu difuziju. Stanice izložene dimetil- $\beta$-ciklodekstrinu $(0,5$ i $1,0 \%)$ i glikokolatu $(0,5 \%)$ nisu uzrokovale značajne promjene TEER-a i aktivnosti mitohondrijske dehidrogenaze (MDH). Rezultati pokazuju da je losartan pogodan za nazalnu isporuku.

Ključne riječi: permeacija, losartan, nazalna apsorpcija, Calu-3 stanice

Biopharmaceutics and Drug Delivery Laboratory, College of Pharmacy, Faculty of Health Professions Dalhousie University, Halifax, NS, Canada B3H 3J5

Pharmacokinetics and Metabolism Laboratory, College of Pharmacy, Faculty of Health Professions Dalhousie University, Halifax, NS, Canada B3H 3J5 